\title{
ВПЛИВ РЕПРОДУКТИВНОГО СЕЗОНУ НА СПЕРМОПРОДУКТИВНІСТЬ ГЕРМІНТАТИВНИХ ХИМЕР СЕЛЕЗНІВ
}

М. С. ДОРОШЕНКО 1 , А. М. ЧЕПІГА ${ }^{1}$, С. О. КОСТЕНКО ${ }^{1}$, П. В. КОРОЛЬ ${ }^{2}$, О. М. КОНОВАЛ ${ }^{3}$, ЛІЖИ ЛУ ${ }^{4}$, ЦЗЮЯНЬЦЯО ХУАНГ ${ }^{4}$, ЛІУМЕНГ ЛІ ${ }^{5}$

${ }^{1}$ Національний університет біоресурсів і природокористування Украӥни (Київ, Україна)

${ }^{2}$ Інститут розведення і генетики тварин імені М.В.Зубия НААН (Чубинське, України)

${ }^{3}$ Лабораторія якості і безпеки продукиї АПК НУБіП України (Чабани, Украӥна)

${ }^{4}$ Інститут тваринництва і ветеринарії Чжецзянської Академії Аграрних Наук (Ханчжоу, Китайська Народна Республіка)

${ }^{5}$ Компанія Чжуизі Гоувей Полтрі Девелопмент (Ханчжоу, Китайська Народна Республіка) mariyamgart@i.ua

У статті наведені результати дослідження спермопродуктивності селезнів порід шаосінь, шанма та герментативних химер. Було встановлено, щу за об'смом еякуляту, концентрацією та активністю сперматозоїдів герментативні химери переважали селезнів порід шаосінь $(P<0,05)$ та шанма $(P<0,01)$. Результати дисперсійного аналізу свідчать, щуо частка впливу породи на об'єм еякуляту становить 25\%, а періоду репродуктивного сезону 13\%. Спермопродуктивність гермінативних химер показує, щзо їх можливо використивувати у біотехнологічних прочедурах по створенню трансгенних качок.

Ключові слова: селезень, спермопродуктивність, химера, генетичний резерв, порівняльний аналіз

\section{INFLUENCE OF THE REPRODUCTIVE SEASON ON THE SPERM PRODUCTION OF THE GERMLINE CHIMERAS OF DRAKES}

M. S. Doroshenko ${ }^{1}$, A. M. Chepiha ${ }^{1}$, S. O. Kostenko ${ }^{1}$, P. V. Korol ${ }^{2}$, O. N. Konoval ${ }^{3}$, Lizhi Lu ${ }^{4}$, Huang Xuetao ${ }^{4}$, Liumeng $\mathrm{Li}^{5}$

${ }^{1}$ National University of Life and Environmental Sciences of Ukraine (Kyiv, Ukraine)

${ }^{2}$ Institute of Animal Breeding and Genetics nd. a. M.V.Zubets of NAAS (Chubynske, Ukraine)

${ }^{3}$ Laboratory of Quality and Safety of AIC Products of NUBiP of Ukraine (Chabany, Ukraine)

${ }^{4}$ Zhejiang Agricultural University College of Animal Science \& Veterinary Medicine (Hangzhou, China)

${ }^{5}$ Zhuji Goveway Poltri Development Company (Hangzhou, China)

This study was conducted to determine the effect of reproductive season on semen characteristics of two chines breeds of ducks Shaoxing and Shan Partridge Duck compare to chimeras, which was created by blastodermal cells method. In experiment we formed 3 groups $(n=6)$, each group receive manual dorso-abdominal massage method that used for semen collection. In the first month of the experiment, sperm was taken 6 times a week, and in the second and third months sperm collection was performed every other day. Color, volume, sperm concentration, motility and sperm number per ejaculate were determined for each ejaculate. Majority of ejaculates were white and had proper consistence. Volume, sperm concentration and motility rate of group 3 was higher compared to group $1(P>0,01)$ and group $2(P>0,05)$ by collection sperm 6 times a week and higher when sperm collection was performed every other day compared to group $1(P<0,001)$ and group $2(P>0,05)$ in reproductive season. As a result of the analysis of qualitative and quantitative indices of the drakes sperm of Shaoxing, Shan Partridge Duck and their germinative chimeras, it was found that the most productive period was April. 
The indicators of sperm production of the germinative chimeras obtained by us indicate their suitability for use in biotechnological procedures for the creation of transgenic animals of this species. Further research consists in the search for molecular markers, which will improve the reproductive qualities of egg drains.

Keywords: drake, sperm production, chimera, genetic reserve, comparative analysis

\section{ВЛИЯНИЕ РЕПРОДУКТИВНОГО СЕЗОНА НА СПЕРМОПРОДУКТИВНИСТЬ ГЕР- МИНТАТИВНИХ ХИМЕРАМИ СЕЛЕЗНЯ}
М. С. Дорошенко
А. М. Чепига ${ }^{1}$,
С. О. Костенко ${ }^{1}$,
П. В. Король ${ }^{2}$,
О. М. Коновал ${ }^{3}$, Лижи Лу ${ }^{4}$, Цзюяньцяо Хуанг ${ }^{4}$, Лиуменг Ли

${ }^{1}$ Национальный университет биоресурсов и природопользования Украиньл (Киев, Украина)

${ }^{2}$ Институт разведения и генетики животных имени М.В.Зубиа НААН (Чубинское, Украина)

${ }^{3}$ Лаборатория качества и безопасности продукиии АПК НАУ Украины (Чабаны, Украина)

${ }^{4}$ Институт жсивотноводства и ветеринарии Чжечзянской Академии аграрньх наук (Ханчжсоу, Китайская Народная Республика)

${ }^{5}$ Компания Чжуцзи Гоувей Полтри Девелопмент (Ханчжоу, Китайская Народная Республика)

В статье приведены результаты исследования спермопродуктивности селезней пород шаосинь, шанма и герментативних химер. Было установлено, что по объему эякулята, концентрацией и активностью сперматозоидов герментативни химеры преобладали селезней пород Шаосинь $(P<0,05)$ и шанма $(P<0,01)$. Результаты дисперсионного анализа свидетельствуют, что доля влияния породы на объем эякулята составляет 25\%, а периода репродуктивного сезона - 13\%. Спермопродуктивнисть герминативных химер показывает, что их можно использовать в биотехнологических процедурах по созданию трансгенных уток.

Ключевые слова: селезень, спермопродуктивнисть, химера, генетический резерв, сравнительный анализ

Використання свійської птиці у якості біореакторів з отримання яєць, які містять у своєму складі рекомбінантні фармацевтичні білки на сьогодні є перспективним науковим напрямком [1].

Одним з ефективних методів створення такої трангенної птиці є отримання герментативних химер $[2,3]$. Однак, внаслідок стерилізації ембріонів частина реципієнтів має погіршені репродуктивні якості. Тому актуальним $\epsilon$ вивчення репродуктивної здатності герментативних химер. Качка (Anas platyrhynchos) є важливим джерелом повноцінних білків тваринного походження. 90\% поголів'я цього виду зосереджено в країнах Азії [4], лідером яких за даними ФАО (2015) є Китай, В'єтнам, Малайзія, Індонезія та ін. Серед європейських країн вирощуванням качок займаються також у Франції, Румунії, Польщі, Україні та ін. [5]. Качині яйця переважають курячі за розміром, калорійністю і вмістом білку [7]. Качки яєчних порід практично не поступаються за продуктивністю курячим [8].

Репродуктивний потенціал самців визначається якістю сперми і має вирішальне значення для успішного відтворення (Peters et al., 2004, Justyna Zawadzka, 2015). Якість еякуляту пов'язана з багатьма факторами. Були вивчені видові та породоспецифічні особливості репродуктивної здатності (Blanco et al., 2000, Peters et al., 2008; Siudzicska and Jukaszewicz, 2008, Tabatabaei et al., 2009, Ajayi et al., 2011, Prieto et al., 2011), вплив віку птиці (Kelso et al., 1996, Jukaszewicz et al., 2000, Pornjit Sonseeda), кліматичних умов (Peters et al., 2008, Ajayi et al., 2011), періоду репродуктивного сезону (Kontecka, 1992, Cheng et al., 2002), умов утримання (Etuk et al., 2006, G. E. Triques) та годівлі (Cerolini et. al., 1995, Al-Daraji and Tahir, 2014, M. P. Macie).

Переважна кількість досліджень присвячена вивченню репродуктивних якостей селезнів м’ясних порід, однак яєчні породи вивчені недостатньо. 
Тому метою даного дослідження було вивчення впливу періоду сезону на якісні та кількісні показники сперми порід Shaoxing (шаосінь), Shan Partridge Duck (шанма) та їх репродуктивної здатності порівняно з герментативними химерами.

Матеріали і методи. Дослідження проведено на качиній фермі компанії Zhejiang Generation Biological Science and Technology Co., Ltd., яка розташована у місті Zhuji провінції Чжецзян на південному сході Китаю за підтримки лабораторії Інституту Чжецзянської академії наук.

Для проведення досліду було сформовано 3 групи селезнів породи шаосінь, шанма та химер 7-місячного віку, по 6 гол. у кожній групі. Тварини відповідали стандарту по породі за живою масою та екстер'єром (National Standard of China, 2012). Сперму від плідників отримували шляхом масажу поперекової частини спини селезнів (Sugimori, 1957).

Для створення тварин-химер використали яйця порід шаосінь (Shaoxing) та шанма (Shan partridge duck). Порода Шаосінь мала рецессивну ознаку - темно-коричневе оперення, порода Шанма несла домінантну ознаку - біло-коричневе оперення.

Біометричну обробку експериментальних даних проводили, відповідно до загальноприйнятих методик, на ПК за допомогою табличного процесора «Microsoft Office Excel - 2010».

Отримання бластодермальних клітин донорів. В якості донорів бластомерів використовували ембріони яєць першої доби після знесення качок породи шаосінь. Бластодиски виділяли з запліднених яєць за допомогою кільця фільтрувального паперу [34]. Отримані ембріони двічі промивали у розчині PBS) (170мM NaCl, 3,4 ммоль KC1, 4мM Na2HPO4, 1,8мМ $\mathrm{KH} 2 \mathrm{RO} 4, \mathrm{pH} 7,2)$ для видалення жовтка. Після цього 10-12 ембріонів переносили до 1 мл PBS, що містить 0,25\% трипсину та 0,04\% EDTA, і інкубували протягом 10 хвилин при температурі $37^{\circ} \mathrm{C}$.

Бластодермальні клітини виділяли шляхом піпетування піпеткою Пастера та центрифугували протягом 10 секунд при 1500 об / хв. Осад ресуспендували в 1 мл середовища RPMI 1640, що містить 10\% фетальної бичачої сироватки. Суспензію клітин концентрували шляхом центрифугування протягом 10 секунд при 1500 об / хв та видаляли 0,7 мл супернатанту. Потім клітини знову ресуспендували в RPMI 1640.

Підготовка яєць реципіснтів. В якості реципієнтів були використані запліднені яйця породи шана (перша доба після знесення). У шкаралупі яєць після обробки їх дезинфікуючим розчином, висушування та опромінення ультрафіолетовим світлом при кімнатній температурі $\left(22-25^{\circ} \mathrm{C}\right)$ протягом 1 години були вирізані отвори (вікна) діаметром $0,7 \mathrm{~cm}$. Після опромінення яйця інкубували 8 годин, потім стерильним пінцетом знімали надрізану шкаралупу, вводили мікроголкою (зовнішній діаметр 50-70 мкм) 600-1000 донорських клітин (34 мкл) під ембріональну порожнину.

Після ін'єкції порожнину яйця заповнювали розчином RPMI 1640 з антибіотиками (ампіцилін і стрептоміцин). Вікно було покрито смугою поліетилової плівки, яка була наклеєна на оболонку з яєчним білком (з яєць донора) та накрита медичним пластирем. Яйця ставили на інкубацію до вилуплення.

Схема експерименту. Дослідження проводили з березня по червень 2017 року. До проведення експерименту селезнів привчали до техніки взяття сперми. У перший місяць досліду сперму відбирали 6 разів за тиждень, а в другий та третій місяці відбір сперми проводився через день. Якісна оцінка свіжої сперми селезнів проводилась одразу після ії взяття. В першу чергу оцінювали колір сперми плідників, наявність забруднення фекальними масами та однорідність консистенції. Зразки, забруднені фекальними масами вибраковувались.

В залежності від об’єму і концентрації сперму розбавляли розріджувачем 1:3, від кожного селезня групи, осіменяли відповідну групу качок.

Об'єм однієї спермодози становив 0,025 мл. Качок осіменяли 1 раз на 7 днів.

Оцінку кількісної спермопродукції здійснювали згідно Інструкції із штучного осіменіння [35]. Об’єм еякуляту визначали за допомогою мірного циліндра та шприцового інжектора на 
10 мкл. Концентрацію сперматозоїдів визначали за допомогою камери Горясва, рухливість сперміїв визначали за допомогою мікроскопа при збільшенні в 300 разів (15Ч20) на столику Морозова $\left(\mathrm{t}=+35-38^{\circ} \mathrm{C}\right)$ за десятибальною шкалою, а виживаємість сперміїв через три години при температурі $+38^{\circ} \mathrm{C}[16]$.

Результати досліджень. Відтворні якості селезнів вивчали протягом 3 місяців за вказаний період дослідження. Основні якісні та кількісні показники сперми селезнів досліджених груп за вказаний період наведено у таблиці 1.

1. Основні якісні та кількісні показники сперми селезнів

\begin{tabular}{|c|c|c|c|c|}
\hline \multirow{2}{*}{ Місяць } & Показник & \multicolumn{3}{|c|}{ Групи селезнів } \\
\cline { 2 - 5 } & Об'єм еякуляту, мл & 1 & 2 & 3 \\
\hline \multirow{5}{*}{ Березень } & Концентрація сперматозоїдів, млрд/мл & $3,619 \pm 0,146$ & $3,746 \pm 0,156$ & $4,060 \pm 0,154$ \\
\cline { 2 - 5 } & Активність сперматозоїдів & 7,1 & 8,3 & 8,9 \\
\cline { 2 - 5 } & Об'єм еякуляту за місяць, мл & 52 & 45 & $67,18 \pm 0,015^{* *(1)}$ \\
\hline \multirow{5}{*}{ Квітень } & Об'єм еякуляту, мл & $0,12 \pm 0,008$ & $0,19 \pm 0,011 * *$ & $0,26 \pm 0,021 * * *($ \\
\cline { 2 - 5 } & Концентрація сперматозоїдів, млрд/мл & $3,679 \pm 0,103$ & $4,724 \pm 0,247$ & $4,773 \pm 0,311$ \\
\cline { 2 - 5 } & Активність сперматозоїдів, бали & 7,8 & 8,8 & 9,1 \\
\cline { 2 - 5 } & Об'єм еякуляту за місяць, мл & 78 & 63 & 75 \\
\hline \multirow{4}{*}{ Травень } & Об'єм еякуляту, мл & $0,14 \pm 0,012$ & $0,17 \pm 0,011$ & $0,24 \pm 0,023 * *(1)$ \\
\cline { 2 - 5 } & Концентрація сперматозоїдів, млрд/мл & $4,141 \pm 0,133$ & $4,712 \pm 0,300$ & $4,914 \pm 0,358$ \\
\cline { 2 - 5 } & Активність сперматозоїдів & 7,7 & 8,5 & 9,1 \\
\cline { 2 - 5 } & Об'єм еякуляту за місяць, мл & 60 & 47 & 55 \\
\hline
\end{tabular}

Примітка: $* P<0,05, * * P<0,01, * * * P<0,001$ до 1 групи

${ }^{1} P<0,05,{ }^{2} P<0,01,{ }^{3} P<0,001$ до 2 групи

1 група: шанма, 2 група: шаосинь, 3 група: химери

У березні максимальне середнє значення об'єму еякуляту мали селезні 3 групи з достовірною різницею порівняно $31(\mathrm{P}<0,01)$ та $2(\mathrm{P}<0,05)$ групами. Середні показники концентрації сперматозоїдів варіювали в межах від 3,619 у групи 1 до 4,060 млрд/мл у групи 3 (табл. 1). Таким чином, 3 група у березні місяці переважала за усіма дослідженими показниками.

У квітні збереглася тенденція щодо кількісних та якісних показників сперми досліджених груп. Селезні 3 групи порівняно $31(\mathrm{P}<0,001)$ та $2(\mathrm{P}<0,05)$ групами мали також максимальне значення середніх показників об'єму еякуляту. Концентрація сперматозоїдів, коливалася від 3,67 (1 група) до 4,77 млрд/мл (3 група) середні показники якої були в межах похибки (табл. 1).

У травні досліджена сперма усіх трьох груп мала різні тенденції щодо змін якісних та кількісних показників. Максимальне середнє значення об'єму еякуляту мали селезні 3 групи, однак вірогідною різниця між цими групами була тільки до 1 групи $(\mathrm{P}<0,01)$. Середні показники концентрації сперматозоїдів були в межах від 4,141 (1 група) до 4,914 млрд/мл (3 група) (табл. 1).

У селезнів першої групи спостерігали сперму від прозоро-білого до молочно-білого кольору середньої консистенції. Сперма селезнів другої та третьої груп характеризувалась молочно-білим або перлово-білим кольором, та сметаноподібною консистенцією. Спостережена нами варіативність кольору та консистенції сперми відповідала аналогічним показн икам описаним для м'ясних качок Cyriac et al. (2013) та (Zawadzka, 2015).

На початку дослідження об'єм еякуляту у селезнів першої групи за середнім значенням був найнижчим $(0,08 \pm 0,014$ мл) серед трьох груп (2 гр -0,12, 3 гр - 0,18 мл). Однак, протягом першого місяця група 1 мала тенденцію збільшення середнього об’ єму сперми $(0,12$ та 
0,14 мл), тоді як групи 2 і 3 показали піковий період, а потім спад (2 гр - 0,19; 0,17, 3 гр - 0,260,24 мл). Об'єм сперми селезнів м'ясних порід за даними Інституту птахівництва УААН характеризується діапазоном від 0,05 до 0,6 мл [25], однак, дослідження Surai and Wishart (1996) свідчать, що об'єм сперми пекінських селезнів був в межах від 0,1 до 0,7 мл, у мускусних качок від 0,05 до 0,5 мл, де ми можемо бачити, що результати об'єму досліджених нами груп качок знаходяться в цих межах. Kamar G.A.R. (1962) порівняв об'єми сперми селезнів різних порід качок і встановив, що у пекінської породи було 0,32 мл, роуен (Rouen) - 0,41 мл, що порівняно з нашими групами результат об'єму вищий, у доміаті (Dumyati) - 0,20 мл, судані 0,18 мл (Sudani) де об’єм еякуляту був аналогічним до результатів представлених нами. У крижнів за даними Stunden et al. (1998) було виявлено 0,04 мл об’єму еякуляту.

Дисперсійний аналіз отриманих нами даних свідчить про те, що частка впливу породи на об'єм еякуляту - 25\%, а періоду репродуктивного сезону - $13 \%$. Активність досліджених нами сперматозоїдів відповідала результатам, отриманим Zawadzka (2015) - 76,28 \% у ХО-01 и 74,66\% у K2. Kamar, G.A.R.(1962) у селезнів пекінської породи було 75\%, (Dumyati) - 60\%, (Rouen) - 77\%, (Sudani) - 80\%. A.I.A. Ghonim (2009) у (Dumyati) від 91,67-95,67\%.

При відборі 6 разів на тиждень концентрація сперматозоїдів селезнів була меншою порівняно з частотою відбору через день в усіх трьох групах. Найвища концентрація сперматозоїдів була в 1 групі - 4,141 х 10\%/мл, у 2 групи - 4,712 х 10\%/мл, 3 групи - 4,914х10\%/мл.

За даними А. I. A. Ghonim (2009) концентрація сперми селезнів дум“яті (Domyati) була $2,48 \times 10^{9} /$ мл и $1,8 \times 10^{9}$ млл. Якщо порівняти отримані нами результати 3 даними інших дослідників, які показали, що у селезнів пекінської породи було 5,85x109/мл (Kamar, G.A.R.(1962)

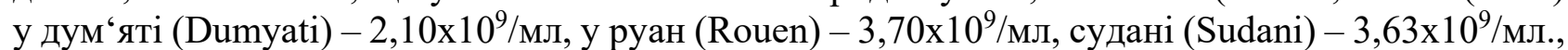
то можна відмітити високий рівень концентрації сперматозоїдів селезнів порід Shaoxing (шаосінь), Shan Partridge Duck (шанма) та їх гермінативних химер.

Однак, за даними Surai and Wishart (1996), які встановили, що концентрація сперматозоїдів у селезнів пекінської породи коливається в межах від 1,5 до 8,0 х 109/мл., таким чином, імовірно, існує високий рівень поліморфізму цього показника, що дозволяє припустити наявність значної кількості факторів різної пироди, які обумовлюють його варіативність.

Висновок. Таким чином, в результаті аналізу якісних та кількісних показників сперми селезнів порід Shaoxing (шаосінь), Shan Partridge Duck (шанма) та їх гермінативних химер було встановлено, що самим продуктивним періодом був квітень.

Показники спермопродуктивності отриманих нами гермінативних химер свідчать про їх придатність до використання у біотехнологічних процедурах по створенню трансгенних тварин цього виду.

Подальші дослідження полягають у пошуку молекулярних маркерів, які дозволять покращити репродуктивні якості селезнів яєчних порід.

\section{БІБЛІОГРАФІЯ}

1. Сураева, Н. М. Получение фармацевтических белков с помощью трансгенной птицы / Н. М. Сураева, А. В. Самойлов // Вестник РОНЦ им. Блохина Н. Н. РАМН. - 2009. - Т. 20, № 4. - C. 19-25.

2. Characterisation and germline transmission of cultured avian primordial germ cells / J. Macdonald, J. D. Glover, L. Taylor, H. M. Sang, M. J. McGrew // PLoS One. - 2010. - Vol. 5, № 11 , e15518.

3. Germline transmission of genetically modified primordial germ cells / M. C. Van de Lavoir, J. H. Diamond, P. A. Leighton, C. Mather-Love, B. S. Heyer, R. Bradshaw, A. Kerchner, L. T. Hooi, T. M. Gessaro, S. E. Swanberg, M. E. Delany, R. J. Etches // Nature. - 2006. - Vol. 441, № 7094. - P. 766-769.

4. Phylogenetic analysis of six duck populations / P. Veeramani, R. Prabakaran, S. N. Sivaselvam, T. Sivakumar, S. T. Selvanand, S. M. K. Karthickeyan // Indian J. Anim. Res. - 2016. - Vol. 50, № 4. - P. 626-628. 
5. Food and agriculture organization of the united nations / (FAO). - 2015. - [Електронний ресурс] - Режим доступу : http://faostat.fao.org/site/573/default.aspx\#ancor.

6. Titlow, Budd. Bird Brains : Inside the Strange Minds of Our Fine Feathered Friends / Titlow, Budd // Rowman and Littlefield.

7. Chi, S. Physicochemical Properties of Salted Pickled Yolks from Duck and Chicken Eggs / S. Chi, and K. Tseng. // Journal of Food Science. - 1998. - Vol. 63. - P. 27-30.

8. Duck / PoultryHub Australia. - 2018. - [Електронний ресурс] - Режим доступу : http://www.poultryhub.org/species/commercial-poultry/duck/

9. Gamal A. Semen characteristics of various breeds of drakes in the subtropics / Gamal A. R. Kamar // J. Reprod. Fertil. - 1962. - Vol. 3. - P. 405-409.

10. Fujihara, N. Genetic resource conservation in poultry reproduction / N. Fujihara, Y. M. Xi, M. J. Zhang // J. App. Anim. Res. - 2001. - Vol. 19. - P. 33-47.

11. Surai, P. F. Poultry artificial insemination technology in the countries of the former USSR / Gamal A. R. Kamar // World Poult. sci. J. - 1996. - Vol. 52, № 1. - P. 27-43.

12. Effect of frequency of semen collection, dilution rate and insemination dose on semen characteristics and fertility of domyati ducks / A. I. A. Ghonim, A. L. Awad, M. A.El-sawy, M. H. Fatouh, Zenat, A. Ibrahiem // Egypt. Poult. sci. - 2009. - Vol. 29. - P. 1023-1045.

13. Justyna Zawadzka. Comparative semen analysis of two Polish duck strains from a conservation programme / Justyna Zawadzka, Ewa Łukaszewicz, and A. Kowalczyk // Europ.Poult.Sci. - 2015. - Vol. 79. - P. 1612-9199.

14. Shaoxing Ducks [S]: DB 33068/T 02.1-2012. Zhuji: Zhuji Quality and Technique Supervision Bureau // National Standard of China. - 2012. - Vol. 40.

15. Semen quality characteristics of White Pekin, Kuttanad (Anas platyrhynchos domesticus) and Muscovy (Cairina moschata momelanotus) drakes / S. Cyriac, L. Joseph, P. A. Peethambaran, K. Narayanankutty, K. Karthiayini // Indian J. Anim. sci. - 2013. - Vol. 83. - P. 595-599.

16. Смирнов, I. В. Штучне осіменіння сільськогосподарських тварин / І. В. Смирнов. - К. : Вища школа, 1976. - $256 \mathrm{c.}$

17. Semen quality traits of seven strain of chickens raised in the humid tropics / S. O. Peters, O. D. Shoyebo, B. M. Ilori, M. O. Ozoje, C. O. N. Ikeobi, O. A. Adebambo // Int. J. Poult. sci. 2008. - Vol. 7. - P. 949-953.

18. Ajayi, F. O. Semen characteristics of three strains of local cocks in the humid tropical environment of Nigeria / F. O. Ajayi, B. O. Agaviezor, P. K. Ajuogu // Int. J. Anim. Veter. Adv. 2011. - Vol. 3. - P. 125-127.

19. Species variation in osmotic, cryoprotectant, and cooling rate tolerance in poultry, eagle, and peregrine falcon spermatozoa / J. M. Blanco, G. Gee, D. E. Wildt, and A. M. Donoghue // Biol. Reprod. - 2000. - Vol. 63. - P. 1164-1171.

20. Lipid and antioxidant changes in semen of broiler fowl from 25 to 60 weeks of age / K. A. Kelso, S. Ceroloni, R. C. Noble, N. H. Sparks, B. K. Speakle // J. Reprod. Fertil. - 1996. - Vol. 106. - P. 201-206.

21. Comparative study on semen quality of one-and two-year-old ganders during the entire reproductive season / E. Łukaszewicz, H. Furuta, Y-M. Xi, N. Fujihara // Asian J. Androl. - 2000. Vol. 2. - P. 139-142.

22. Kontecka, H. Sperm quality changes in drakes during the reproductive season / H. Kontecka // Rocz. Nauk. Zoot. - 1992. - Vol. 1, № 19. - P. 9-18.

23. Annual variation in semen characteristics of pigeons (Columbia livia) / F. P. Cheng, T. J. Guo, J. T. Wu, T. E. Lin, P. J. F. Ursen, B. Colenbrander, H. P. Fung // Poult. sci. - 2002. - Vol. 81. - P. $1050-1056$.

24. Etuk, I. F. Effect of management systems on semen quality of Muscovy drakes / I. F. Etuk, G. S. Ojewola, E. N. Nwachukwu // Int. J. Poult. sci. - 2006. - Vol. 5. - P. 482-484. 
25. Effect of restricted and ad libitum feeding on semen production and fertility in broiler breeder males / S. Cerolini, C. Mantovani, F. Bellagamba, M. G. Mangiagalli, L. G. Cavalchini, R. Reniero // Br. Poult. sci. - 1995. - Vol. 36. - P. 677-682.

26. Al-Daraji, H. J. Effect of L-carnitine supplementation on drake semen quality / H. J. AlDaraji, and A. O. Tahir // S. Afr. J. Anim. sci. - 2014. - Vol. 44. - P. 18-25.

27. Tabatabaei, S. Comparison of semen quality in indigenous and Ross broiler breeder roosters / S. Tabatabaei, R. A. Batavani, and A. R. Talebi // J. Anim. Vet. Advan. - 2009. - Vol. 8. - P. 9093.

28. Siudzińska, A. Effect of semen extenders and storage time on sperm morphology of four chicken breeds / A. Siudzińska, E. Łukaszewicz // J. Appl. Poult. Res. - 2008. - Vol. 17. - P. 101108.

29. Prieto, M. T. Relationship among fluctuating asymetry, morphological traits, and sperm quality in layers / M. T. Prieto, J. L. Campo, J. Santiago-Moreno // Poult. sci. - 2011. - Vol. 90. P. 2845-2854.

30. Pornjit Sonseeda. Effects of Environmental Factors, Ages and Breeds on Semen Characteristics in Thai Indigenous Chickens: A One-year Study / Pornjit Sonseeda, Thevin Vongpralub, Banyat Laopaiboon // Thai J Vet Med. - 2013. - Vol. 43, № 3. - P. 347-352.

31. Efeito da suplementação dietética de antioxidantes sobre características reprodutivas de machos reprodutores de frangos de corte na fase pós pico de produção / G. E. Triques, J. M. Schmidt, C. S. Oro, H. F. Bordignon, D. G. Donin, J. I. M. Fernandes // Ciências Agrárias, Londrina. - 2016. - Vol. 37, № 4. - P. 2557-2566.

32. Programas de luz sobre o desempenho e parâmetros seminais de galos semi-pesados / M. P. Macie, J. T. De B. Cotta, L. D. S. Murgas, D. De Lima, F. P. Lima, A. L. N. Alvarenga// Ciência Rural, Santa Maria. - 2011. - Vol. 41, № 9. - P. 1617-1621.

33. Артеменко, А. Б. Особенности репродукции сельскохозяйственной птицы. Сперма птиц, её особенности, основные показатели и методы оценки. Качество спермы как один из факторов определяющих оплодотворенность яиц / А.Б. Артеменко // www.tagirovm.narod.ru/Reproduction/SpermQuality.pdf

34. Тагиров, М. Т. Получение химер получение химер герминативной линии птиц/ М. Т. Тагиров // Биотехнология. - 2010. - Т. 3, № 2. - С. 82-88.

35. Підвищення кваліфікації техників штучного осіменіння сільськогосподарських тварин и птиці / І. В. Лобачова, Г. І. Буюклу, П. Г. Жарук, В. С. Яковчук, О. М. Крилова. - К. : Агроосвіта, 2015. - 17 c.

\section{REFERENCES}

1. Suraeva, N. M., and A. V. Samojlov. 2009. Poluchenie farmacevticheskih belkov s pomoshh'ju transgennoj pticy - Preparation of pharmaceutical proteins using transgenic poultry. Vestnik RONC im. N. N. Blohina RAMN. 20(4):19-25 (in Russian).

2. Macdonald, J., J. D. Glover, L. Taylor, H. M. Sang, M. J. McGrew. 2010. Characterisation and germline transmission of cultured avian primordial germ cells. PLoS One 5 (11):e15518.doi:10.1371/journal.pone.0015518 (in English).

3. Van de Lavoir, M. C., J. H. Diamond, P. A. Leighton, C. Mather-Love, B. S. Heyer, R. Bradshaw, A. Kerchner, L. T. Hooi, T. M. Gessaro, S. E. Swanberg, M. E. Delany, and R. J. Etches. 2006. Germline transmission of genetically modified primordial germ cells. Nature. 441(7094):766769. doi:10.1038/nature04831 (in English).

4. Veeramani, P., R. Prabakaran, S. N. Sivaselvam, T. Sivakumar, S. T. Selvanand, S. M. K. Karthickeyan. 2016. Phylogenetic analysis of six duck populations. Indian J. Anim. Res. 50(4):626-628 (in English).

5. 2015. Food and agriculture organization of the united nations / (FAO). - [Elektronnyy resurs] Access mode : http://faostat.fao.org/site/573/default.aspx\#ancor (in English). 
6. Titlow, Budd. 2013. Bird Brains : Inside the Strange Minds of Our Fine Feathered Friends. Rowman and Littlefield (in English).

7. Chi, S., and K. Tseng. 1998. Physicochemical Properties of Salted Pickled Yolks from Duck and Chicken Eggs. Journal of Food Science. 63:27-30. doi:10.1111/j.1365-2621.1998.tb15668.x (in English).

8. Duck. 2018. PoultryHub Australia. - [Elektronnyy resurs] - Access mode : http://www.poultryhub.org/species/commercial-poultry/duck/ (in English).

9. Gamal A. R. Kamar. 1962. Semen characteristics of various breeds of drakes in the subtropics. J. Reprod. Fertil. (3):405-409 (in English).

10. Fujihara, N., Y. M. Xi, and M. J. Zhang. 2001. Genetic resource conservation in poultry reproduction. J. App. Anim. Res. 19:33-47 (in English).

11. Surai, P. F., and G. J. Wishart. 1996. Poultry artificial insemination technology in the countries of the former USSR. World Poult. sci. J. 52(1):27-43 (in English).

12. Ghonim, A. I. A., A. L. Awad, M. A.El-sawy, M. H. Fatouh, and Zenat, A. Ibrahiem. 2009. Effect of frequency of semen collection, dilution rate and insemination dose on semen characteristics and fertility of domyati ducks. Egypt. Poult. sci. 29(IV):1023-1045 (in English).

13. Justyna Zawadzka, Ewa Łukaszewicz, and A. Kowalczyk. 2015.Comparative semen analysis of two Polish duck strains from a conservation programme. Europ. Poult. sci. 79:1612-9199 (in English).

14. Shaoxing Ducks [S]: DB 33068/T 02.1-2012.Zhuji: Zhuji Quality and Technique Supervision Bureau. 2012. National Standard of China. 40 (in English).

15. Cyriac, S., L. Joseph, P. A. Peethambaran, K. Narayanankutty, K. Karthiayini. 2013. Semen quality characteristics of White Pekin, Kuttanad (Anas platyrhynchos domesticus) and Muscovy (Cairina moschata momelanotus) drakes. Indian J. Anim. sci. 83:595-599 (in English).

16. Smirnov, I. V. 1976. Shtuchne osimeninnja sil's'kogospodars'kih tvarin. K. Vishha shkola. 256 (in Ukranian).

17. Peters, S. O., O. D. Shoyebo, B. M. Ilori, M. O. Ozoje, C. O. N. Ikeobi, and O. A. Adebambo. 2008. Semen quality traits of seven strain of chickens raised in the humid tropics. Int. J. Poult. sci. 7:949-953 (in English).

18. Ajayi, F. O., B. O. Agaviezor, and P. K. Ajuogu. 2011. Semen characteristics of three strains of local cocks in the humid tropical environment of Nigeria. Int. J. Anim. Veter. Adv. 3:125-127 (in English).

19. Blanco, J. M., G. Gee, D. E. Wildt, and A. M. Donoghue. 2000. Species variation in osmotic, cryoprotectant, and cooling rate tolerance in poultry, eagle, and peregrine falcon spermatozoa. Biol. Reprod. 63:1164-1171 (in English).

20. Kelso, K. A., S. Ceroloni, R. C. Noble, N. H. Sparks, and B. K. Speakle. 1996. Lipid and antioxidant changes in semen of broiler fowl from 25 to 60 weeks of age. J. Reprod. Fertil. 106:201206 (in English).

21. Łukaszewicz, E., H. Furuta, Y-M. Xi, and N. Fujihara. 2000. Comparative study on semen quality of one-and two-year-old ganders during the entire reproductive season. Asian J. Androl. 2:139-142 (in English).

22. Kontecka, H. 1992. Sperm quality changes in drakes during the reproductive season. Rocz. Nauk. Zoot. 1(19):9-18 (in English).

23. Cheng, F. P., T. J. Guo, J. T. Wu, T. E. Lin, P. J. F. Ursen, B. Colenbrander, and H. P. Fung. 2002. Annual variation in semen characteristics of pigeons (Columbia livia). Poult. sci. 81:10501056 (in English).

24. Etuk, I. F., G. S. Ojewola, E. N. Nwachukwu. 2006. Effect of management systems on semen quality of Muscovy drakes. Int. J. Poult. sci. 5:482-484 (in English).

25. Cerolini, S., C. Mantovani, F. Bellagamba, M. G. Mangiagalli, L. G. Cavalchini, and R. Reniero. 1995. Effect of restricted and ad libitum feeding on semen production and fertility in broiler breeder males. Br. Poult. sci. 36:677-682 (in English). 
26. Al-Daraji, H. J., and A. O. Tahir. 2014. Effect of L-carnitine supplementation on drake semen quality. S. Afr. J. Anim. sci. 44:18-25 (in English).

27. Tabatabaei, S., R. A. Batavani, and A. R. Talebi. 2009. Comparison of semen quality in indigenous and Ross broiler breeder roosters. J. Anim. Vet. Advan. 8:90-93 (in English).

28. Siudzińska, A., and E. Łukaszewicz. 2008. Effect of semen extenders and storage time on sperm morphology of four chicken breeds. J. Appl. Poult. Res. 17:101-108 (in English).

29. Prieto, M. T., J. L. Campo, and J. Santiago-Moreno. 2011. Relationship among fluctuating asymetry, morphological traits, and sperm quality in layers. Poult. sci. 90:2845-2854 (in English).

30. Pornjit Sonseeda, Thevin Vongpralub, Banyat Laopaiboon. 2013. Effects of Environmental Factors, Ages and Breeds on Semen Characteristics in Thai Indigenous Chickens: A One-year Study. Thai J Vet Med. 43(3):347-352 (in English).

31. Triques, G. E., J. M. Schmidt, C. S. Oro, H. F. Bordignon, D. G. Donin, and J. I. M. Fernandes. 2016. Efeito da suplementação dietética de antioxidantes sobre características reprodutivas de machos reprodutores de frangos de corte na fase pós pico de produção. Ciências Agrárias, Londrina. 37.4(1):2557-2566.

32. Macie, M. P., J. T. De B. Cotta, L. D. S. Murgas, D. De Lima, F. P. Lima, and A. L. N. Alvarenga. 2011. Programas de luz sobre o desempenho e parâmetros seminais de galos semi-pesados. Ciência Rural, Santa Maria. 41(9):1617-1621.

33. Artemenko, A. B. Osobennosti reprodukcii sel'skohozjajstvennoj pticy. Sperma ptic, ejo osobennosti, os-novnye pokazateli i metody ocenki. Kachestvo spermy kak odin iz faktorov opredeljajushhih oplodotvorennost' jaic - Features of reproduction of agricultural birds. Bird sperm, its features, main indicators and methods of evaluation. Quality of sperm as one of the factors determining the fertilization of eggs. [Elektronnyy resurs]. - Access mode : www.tagirovm.narod.ru/Reproduction/SpermQuality.pdf (in Russian).

34. Tagirov, M. T. 2010. Poluchenie himer poluchenie himer germinativnoj linii ptic - Obtaining chimeras obtaining chimeras of the germinal line of birds. Biotechnologija. 3(2):82-88 (in Russian).

35. Lobachova, I. V., G. I. Bujuklu, P. G. Zharuk, V. S. Jakovchuk, and O. M. Krilova. 2015. Pidvyshchennia kvalifikatsii tekhnykiv shtuchnoho osimeninnia silskohospodarskykh tvaryn y ptytsi - Improving the qualification of artificial insemination of farm animals and poultry. Agroosvita. 17 (in Ukrainian). 